\title{
Assessment of wind resources and short-term power prediction in Lithuania
}

Giedrius Gecevičius,

Mantas Marčiukaitis,

Antanas Markevičius,

Vladislovas Katinas

Laboratory for Renewable Energy

and Energy Efficiency,

Lithuanian Energy Institute,

Breslaujos str. 3,

LT-44403 Kaunas, Lithuania

E-mail: giedrius.gecevicius@lei.lt; mantas.marciukaitis@lei.lt; antanas.markevicius@lei.lt; vladislovas.katinas@lei.lt
The installed wind power in Lithuania reached $422 \mathrm{MW}$ in 2015, and it was one of the most developing renewable energy sectors in the country. For this reason, it is important to estimate wind energy potential and the tendencies of wind power prediction accuracy. In this work, the results of statistical analysis of wind measurements in a number of locations in Lithuania are presented, which makes the basis for wind energy potential estimation. Wind power prediction errors of different time scales have been analysed, and the influence of seasonal and diurnal wind power variation is pointed out. Also, the possibilities of connection of new wind farms to the grid are analysed in the paper. Investigation shows that northern and middle regions of Lithuania are the most favourable for further wind power development with the goal of reaching the total installed power of $840 \mathrm{MW}$ till 2030.

Key words: wind energy, energy potential, power prediction

\section{INTRODUCTION}

Wind energy is among the fastest developing renewable energy sectors globally. In 2014, 51 GW of new wind power capacity was added, and global installed wind power capacity reached $370 \mathrm{GW}$. Currently China, USA and Germany are the leaders of new annual wind power installations [1]. Lithuania keeps up the pace of wind farm expansion, reaching $422 \mathrm{MW}$ of installed power in 2015. Intensive development is foreseen in the future - there are plans to have at least $840 \mathrm{MW}$ of total capacity till 2030 [2]. However, such plans require analysis of possibilities to connect wind farms to the national grid and a more detailed estimation of wind potential. Besides, wind power development is typically a challenge for the grid operator and is accompanied by the issues of grid balance and required reserves $[3,4]$. The solutions of this kind of problems are facilitated by using wind power prediction systems and improving their accuracy $[5,6]$.

One of the major limiting factors for wind power development is spare grid capacity. Most wind farms around the Baltic Sea are typically constructed close to the seashore, where wind resource is the highest. However, the grid may not be sufficiently strong to accept the increasing amount of wind power, which consequently has to be transmitted deeper inland [3, 7]. Wind speed variation results in significant wind power fluctuations leading to the challenges of grid balancing [8]. This issue needs professional approach using state-of-the-art wind speed and power prediction systems [9].

On a global scale, wind power generation is influenced by topographical and meteorological conditions. On a regional scale, wind speed varies according to the geographical location depending on the sizes of land and sea and the presence of 
mountains and plain areas [10]. For Lithuania, one of the most important factors influencing local and regional wind conditions is the terrain forestation level. Optimal combination of this factor together with transmission network capacity and adequacy of active power regulation reserves determines possibilities for sustainable wind power development [11].

Several main types of models are used for wind power prediction: time series, statistic and physical models $[12,13]$. Also, combined hybrid models can be used which have been proved as giving the best forecast results [14]. These models and forecasts are used to predict the wind power output of a stand-alone wind turbine or a wind farm. From various terms and categorizations of the prediction horizon which may be found in literature there are three typical prediction horizons used: very short-term - from several seconds to 1 hour, used for wind farm operation control; short-term - 1-72 hours (up to 3 days), used for load determination and planning in advance, electricity market, cost optimization; and medium-term (from 3 to 7 days), used for planning of wind farm maintenance works and allocation of other power generation sources [15].

Despite improvements in wind power forecasting methods, wind power forecasts still suffer from relatively high errors, depending on several factors, such as forecasting horizon, type of forecasting model, size of wind farm and geographic location $[16,17]$. Also, research works show that wind power prediction errors depend on seasonal and diurnal wind variations, as well as local topographical and meteorological conditions $[18,8]$. As a result of this, it is very important to analyse seasonal, diurnal and hourly forecast errors and their dependence on wind speed, local topographical characteristics, air temperature inversion and air flow vertical and horizontal stratification [19].

\section{MATERIALS AND METHODS}

In this work, one-year (2014) wind measurement data from one 100-m meteorological mast and a number of meteorological stations (masts of $10 \mathrm{~m}$ in height) around Lithuania were used. Hourly data from the met-stations were converted to $100 \mathrm{~m}$ height (typical hub-height of modern wind turbines) using a simple power law (equa- tion 1). Two values of shear coefficients were chosen for calculation: 0.28 (small settlement, suburbs) and 0.375 (medium size town). These values represent the terrain roughness of the real locations of the met-stations [20]:

$$
v_{2}=v_{1}\left(\frac{h_{2}}{h_{1}}\right)^{k},
$$

where $v_{2}$ is wind speed at $100 \mathrm{~m}, v_{1}$ is wind speed at $10 \mathrm{~m}, h_{1}$ is the height of the mast at the meteorological station, $h_{2}$ is the height chosen for wind speed conversion $(100 \mathrm{~m}), k$ is the wind shear coefficient (0.28 - small settlement, suburbs, 0.375 - medium size town).

Wind speed probability is described by the Weibull distribution (equation 2), wind direction distribution is illustrated by a wind rose. WAsP 9 software was used for the calculations:

$$
p(v)=\frac{k}{v} *\left(\frac{v}{A}\right)^{k-1} e^{-\left(\frac{A}{v}\right)^{k}}
$$

where $p(v)$ is probability of wind speed $v$ occurrence, $k$ is the Weibull distribution shape parameter, $A$ is the Weibull distribution scale parameter.

Wind farm actual and predicted power data from the Lithuanian electricity transmission system operator (Litgrid $A B$ ) were used for the estimation and analysis of prediction errors. Several types of errors were used for the evaluation of wind power prediction accuracy. As hourly data is available for the period of last five years (20102014), seasonal and annual prediction errors were distinguished. The results of wind power prediction error analysis are given in hourly intervals. Analysis of diurnal variations was carried out using 3-hour intervals from 00:00 to 24:00. This analysis covers the same last five-year period.

Annual wind power prediction error variability is related to seasonal variations. To estimate annual, seasonal and diurnal errors, their relative values were calculated according to equation

$$
f=\frac{x}{c} * 100 \%
$$

where $f$ is a relative wind power prediction error (per cent), $x$ is an hourly absolute wind power 
prediction error $(\mathrm{MW}), c$ is installed wind power capacity (MW).

The RMSE (root mean squared error) was calculated using a typical equation

$$
R M S E=\sqrt{\sum_{i=1}^{n}\left(x_{i}-y_{i}\right)^{2}},
$$

where $x_{i}$ is actual wind power (MW), $y_{i}$ is predicted wind power (MW).

The MAE (mean absolute error) was calculated using the equation

$$
M A E=\left|x_{i}-y_{i}\right|,
$$

where $x_{i}$ is actual wind power (MW), $y_{i}$ is predicted wind power $(\mathrm{MW})$.

\section{RESULTS}

\section{Wind power development in Lithuania}

The final electricity consumption in Lithuania (including grid losses) equalled 10.05 TWh in 2014; $63.9 \%$ of the gross electricity consumption was imported. To compare renewable energy sources, wind turbines generated $14.5 \%$, hydro power plants $9.1 \%$, photovoltaic $1.7 \%$ of total electricity produced in Lithuania in 2014 (Fig. 1).

In 2014, the maximum power demand in Lithuania reached $1810 \mathrm{MW}$, and installed power capacity was significantly larger - $4296 \mathrm{MW}$ (Table 1). However, electricity production in obsolete thermal power plants was inefficient due to combustion of expensive imported fossil fuel, mainly natural gas.

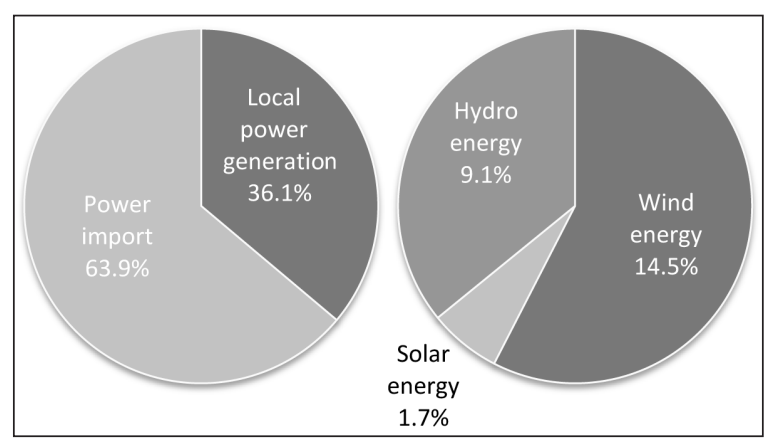

Fig. 1. Distribution of imported power and local generation $(a)$ and parts of electricity generated in wind, solar and hydro power plants in the total local generation (b) in Lithuania in 2014 [2]
Table 1. Actual and forecasted power generation and consumption in Lithuania (Lithuanian Electricity Transmission System 0p-

\begin{tabular}{|c|c|c|c|}
\hline & & 2014 & 2023 \\
\hline Electricity demand & TWh & 10.72 & 13 \\
\hline Maximum power demand & MW & 1810 & 2200 \\
\hline Installed power capacity in total & MW & 4296 & 4898 \\
\hline \multicolumn{4}{|c|}{ Power plants for power generation } \\
\hline Thermal power plants & MW & 2827 & 2418 \\
\hline $\begin{array}{l}\text { Hydro and hydro pump storage power } \\
\text { plants }\end{array}$ & MW & 1028 & 1267 \\
\hline Other renewable energy sources & MW & 441 & \\
\hline Wind energy & MW & 285 & \\
\hline Biomass energy & MW & 92 & \\
\hline Solar energy & MW & 68 & 1213 \\
\hline
\end{tabular}
erator Litgrid, 2015)

The dependence of the Lithuanian power system on import was determined by the supply of cheap electricity in the markets of neighbouring countries. In the course of several years, final power (electricity) demand remained stable, and the share of electricity from renewable sources in the national balance increased to $18 \%$.

The development of wind energy started only ten years ago, and the last decade was a period of gradual wind power development in Lithuania. The first wind turbine $(630 \mathrm{~kW})$ was built in 2004. In 2006, the first wind park of 15 turbines (installed capacity $2 \mathrm{MW}$ each) was erected and connected to the electricity transmission network. At the end of 2005, the total capacity of all installed wind turbines was 6.4 MW, but in 2014 it reached $285 \mathrm{MW}$ (Table 2).

Wind power provided approximately $6.9 \%$ of the final electricity consumption in Lithuania, and it was the biggest renewable energy source for power generation in Lithuania in 2014. At the end of 2015, installed wind power capacity reached $422 \mathrm{MW}$.

Successful development of wind energy requires evaluation of spare grid capacity for connection of wind farms. The researchers of the Kaunas University of Technology together with specialists from Litgrid $A B$ have analysed possible wind power development scenarios [2]. The minimum scenario foresees the total installed capacity of 500 MW till 2030, medium scenario - $670 \mathrm{MW}$, and ambitious scenario - $840 \mathrm{MW}$. 
Table 2. Wind power development in Lithuania in 2004-2014

\begin{tabular}{c|c|c|c|c|c|c|c|c|c|c|c}
\hline & $\mathbf{2 0 0 4}$ & $\mathbf{2 0 0 5}$ & $\mathbf{2 0 0 6}$ & $\mathbf{2 0 0 7}$ & $\mathbf{2 0 0 8}$ & $\mathbf{2 0 0 9}$ & $\mathbf{2 0 1 0}$ & $\mathbf{2 0 1 1}$ & $\mathbf{2 0 1 2}$ & $\mathbf{2 0 1 3}$ & $\mathbf{2 0 1 4}$ \\
\hline Installed power MW & 0.215 & 1 & 49 & 52 & 54 & 90 & 155 & 202 & 274 & 281 & 285 \\
\hline $\begin{array}{c}\text { Electricity produced } \\
\text { GWh }\end{array}$ & 1.2 & 1.78 & 13.7 & 106.1 & 131 & 157 & 223.2 & 472.5 & 537.7 & 600 & 639.1 \\
\hline $\begin{array}{c}\text { Share of final electricity } \\
\text { consumption \% }\end{array}$ & 0.02 & 0.02 & 0.1 & 0.8 & 1.1 & 1.4 & 2 & 4.4 & 5 & 5.5 & 6.9 \\
\hline
\end{tabular}

In this study, the points of the connection of maximum allowed wind power capacities were determined. A map was created by Litgrid $A B$ showing spare connection capacities for wind farms. Information presented on this map leads to the conclusion that possibilities for wind farms connection in the western part of Lithuania, particularly in the coastal region, are practically depleted (Fig. 2).

Grid capacities in other regions are sufficient for intensive wind power development. The study also indicates that the total new wind power capacity to be connected to the grid must not exceed 1000 MW. Construction of new power lines would not be necessary if new wind farms were geographically widely distributed; it would be enough to implement the planned infrastructure projects [2].

\section{Assessment of wind power potential in}

\section{Lithuania}

Wind energy potential has been estimated in order to determine the most favourable regions for

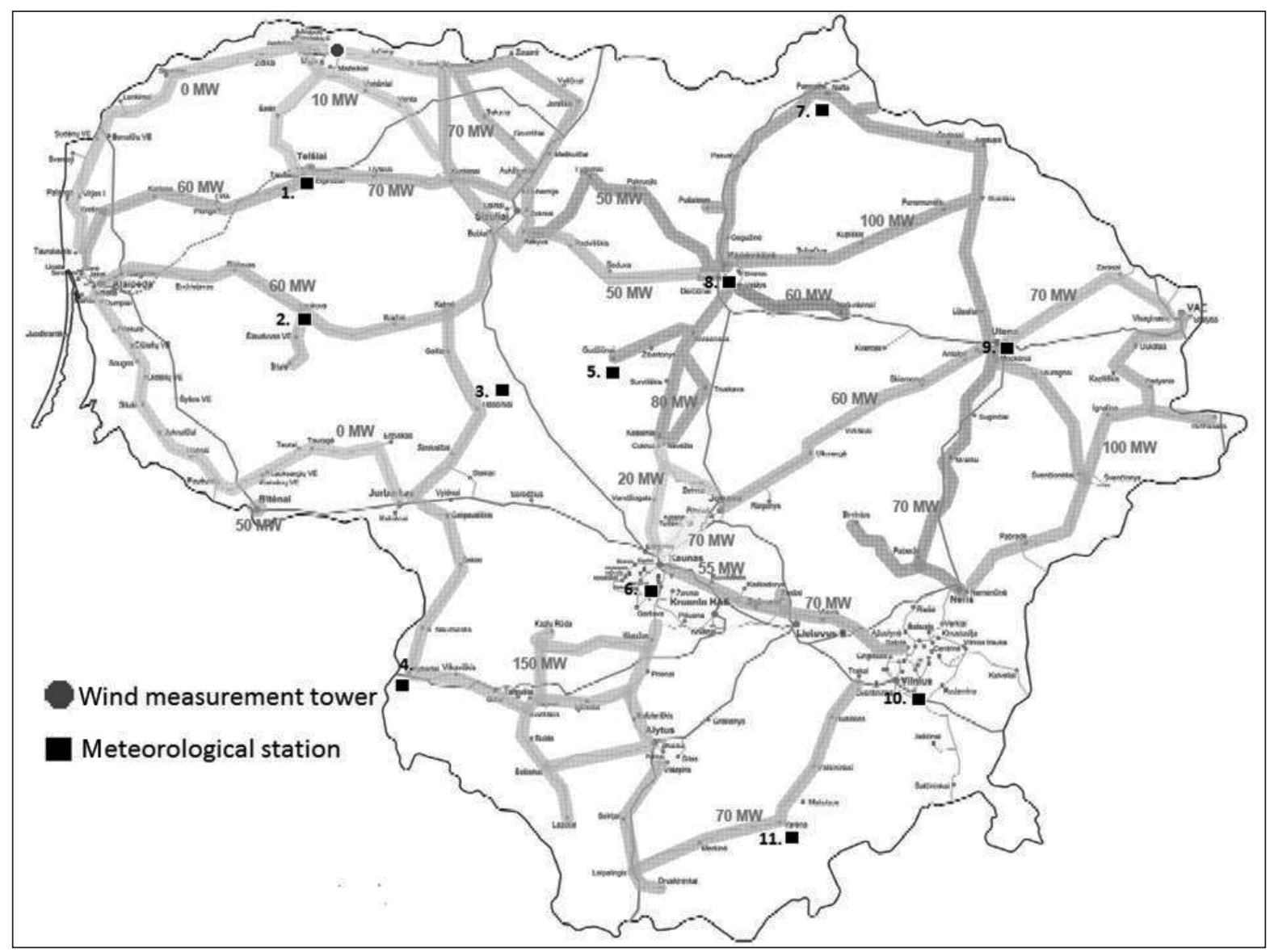

Fig. 2. Map of the electricity grid spare capacities for wind power connection. Meteorological stations: 1 - Telšiai, 2 - Laukuva, 3 - Raseiniai, 4 - Kybartai, 5 - Dotnuva, 6 - Kaunas, 7 - Biržai, 8 - Panevežys, 9 - Utena, 10 - Vilnius, 11 - Varėna 
wind power development. Hourly wind measurement data from 11 Lithuanian meteorological stations and one tall measurement mast were used for the statistical analysis. Measurements covered one full year (2014), and wind speed from $10 \mathrm{~m}$ was converted to the wind speed at the height of $100 \mathrm{~m}$, except for the tall tower with measurement data from $100 \mathrm{~m}$ height. The Weibull distribution function was used for the approximation of the converted wind speed data.

Due to a non-complex terrain in Lithuania, these statistical values represent wind climate in a relatively large region around the measurement mast. Local roughness and terrain effects were taken into account using wind shear values typical of the surroundings of meteorological stations.

The observed wind climate results consist of wind rose, wind speed distribution histogram, annual mean speed at $100 \mathrm{~m}$ heights, power density $\left(\mathrm{W} / \mathrm{m}^{2}\right)$ and prevailing wind directions (Fig. 3). In the plots of the observed wind speed distribution, the Weibull parameters (scale parameter $A$ and shape parameter $k$ ) are also given.

Mean wind speeds and power densities are listed in Table 3. It can be noticed that wind power values do not correlate with the mean wind speed values. This is because wind power values are not based on the mean wind speed. They were calculated taking into account wind speed distribution. Besides, different wind shear values were used for wind speed recalculation for $100 \mathrm{~m}$ height.

It can be seen from Table 3 that the highest wind speeds at $100 \mathrm{~m}$ height were calculated in the western part of Lithuania - from 6.2 to $7.9 \mathrm{~m} / \mathrm{s}$. Meanwhile in the eastern and southern parts, wind speed is the lowest - reaches only $4.8 \mathrm{~m} / \mathrm{s}$.

Analysis of wind statistical data reveals a rather large variation of wind conditions in different regions of Lithuania. Weibull $k$ parameter values vary in the range from 1.85 (Kybartai) to 2.58 (Mažeikiai), which indicates a lower scatter of wind speeds in the northern part. The scale parameter $A$ varies from $5.4 \mathrm{~m} / \mathrm{s}$ (Utena) to $8.8 \mathrm{~m} / \mathrm{s}$ (Laukuva). The lowest power density was recorded in Varena $\left(134 \mathrm{~W} / \mathrm{m}^{2}\right)$, and the highest in Laukuva $\left(607 \mathrm{~W} / \mathrm{m}^{2}\right)$.

Wind energy can be efficiently harvested in zones, where the average wind speed at 100 meters above the ground exceeds 6-7 m/s [21]. According to analysis, in Lithuania such zones are
Table 3. Statistical wind data from meteorological stations

\begin{tabular}{c|c|c|c}
\hline $\begin{array}{c}\text { Metrological } \\
\text { station }\end{array}$ & $\begin{array}{c}\text { Average wind } \\
\text { speed at } \mathbf{1 0 0} \mathbf{~ m} \\
(\mathbf{m} / \mathbf{s})\end{array}$ & $\begin{array}{c}\text { Power } \\
\left(\mathbf{W} / \mathbf{m}^{2}\right)\end{array}$ & $\begin{array}{c}\text { Prevailing } \\
\text { wind direction }\end{array}$ \\
\hline Telšiai & 6.2 & 259 & South \\
\hline Biržai & 7.1 & 545 & South \\
\hline Panevezžys & 6.6 & 368 & Southeast \\
\hline Laukuva & 7.8 & 607 & Southeast \\
\hline Utena & 4.8 & 124 & Southeast \\
\hline Raseiniai & 6.6 & 346 & South \\
\hline Kaunas & 6.6 & 341 & Southeast \\
\hline Kybartai & 6.2 & 305 & Southwest \\
\hline Vilnius & 6.7 & 376 & Southeast \\
\hline Varėna & 4.8 & 134 & Southeast \\
\hline Dotnuva & 5.6 & 205 & South \\
\hline Mažeikiai* & 6.4 & 244 & Southwest \\
\hline
\end{tabular}

* data from a $100 \mathrm{~m}$ meteorological tower

situated mostly at the Baltic seacoast. The most favourable wind energy potential is located in western and north-western Lithuania. Wind measurements show that eastern and southern parts of Lithuania stand out with the worst wind conditions - wind speed does not exceed the $5 \mathrm{~m} / \mathrm{s}$ threshold at $100 \mathrm{~m}$ height, and power density is lower than $200 \mathrm{~W} / \mathrm{m}^{2}$. Due to the fact that wind power development possibilities regarding the connection to the electricity grid are at the limit of exploitation in the western regions (Fig. 2), further perspectives for the installation of new wind power capacities are related to the unexploited potential in the middle and northern regions of Lithuania.

\section{Wind power prediction in Lithuania}

The exploitation of wind power is receiving increased attention during the last 10 years in Lithuania. In this period, the accurate estimation of available energy potential for short- or long-term forecasting horizons is of primary importance but not always easy to be achieved due to the variable form and complexity of environmental conditions that are directly or indirectly involved. For wind power prediction, two models are currently used in Lithuania: Aiolos and Wind Power Prediction Tool (WPPT). Analysis of prediction errors revealed that in recent years, the accuracy of wind power prediction improved. The main reason for 


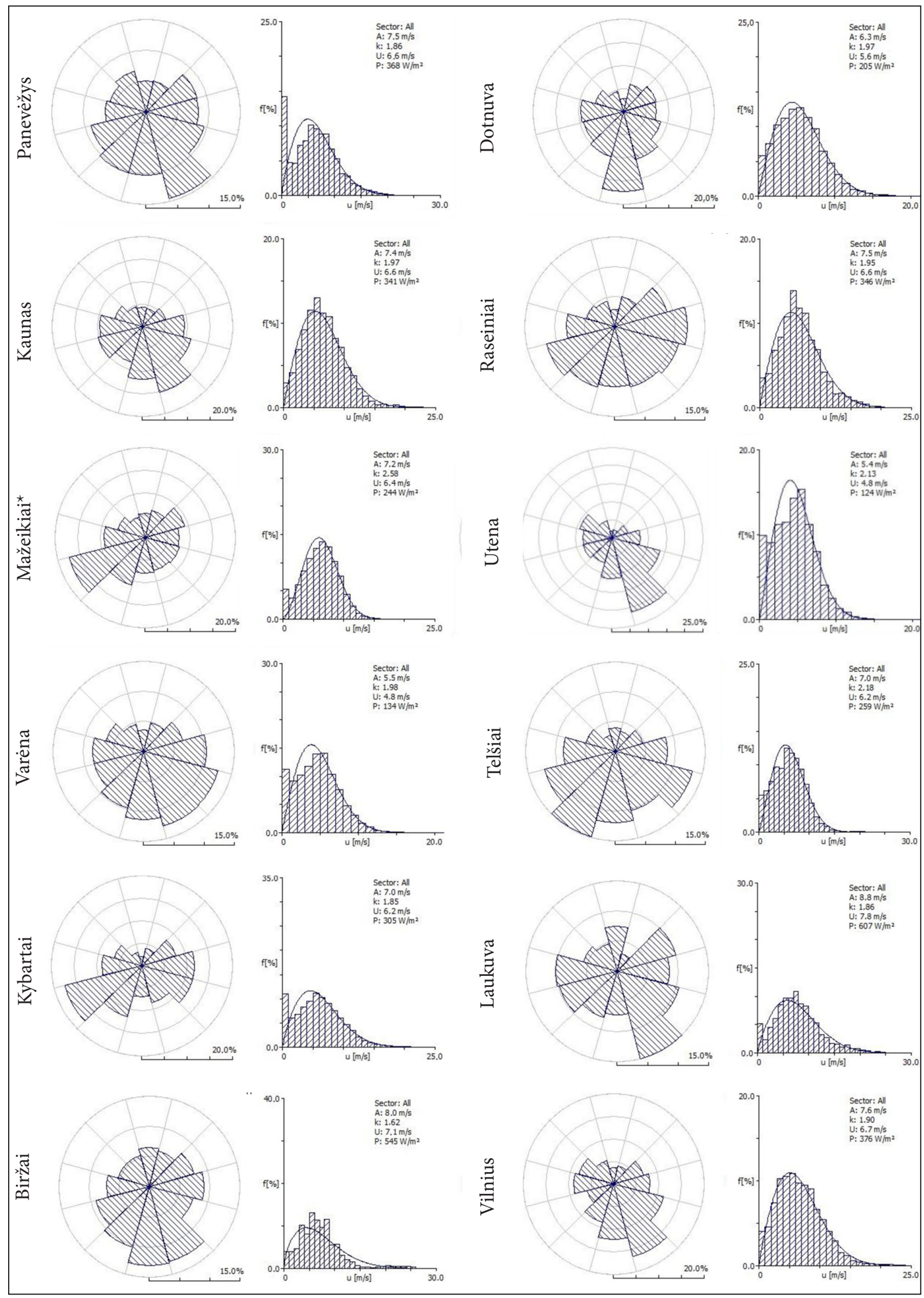

Fig. 3. One-year wind speed and direction statistics at $100 \mathrm{~m}$ height in different regions in Lithuania (wind rose and Weibull distribution, respectively) 
this is the adoption of historical wind speed and power data in prediction models. The second reason is the introduction of predictions two times per day since February 2014, i. e., at 9:00 and 14:00 during the day. In total, the mean absolute error (MAE) of wind power prediction reached $5.9 \%$ in 2014 in Lithuania.

Differences between the actual and forecasted Lithuanian wind farm power in January 2015 are given in Fig. 4. Results indicate that actual data follow the predictions quite well; however, sometimes rather large errors may occur. During the given month, the biggest forecast errors were 91 MW (32\% of total installed capacity) (Fig. 4).

The diurnal wind power prediction variation is presented in Fig. 5. Diurnal variations reveal discrepancy between power prediction and actu- al power generation. If such discrepancies occur frequently, this may result in significant yearly losses of the TSO. For this reason, it is very important to analyse wind power prediction errors and increase prediction accuracy. This may be done through analysis of seasonal and diurnal prediction errors and their origin.

Wind power prediction errors also depend on installed wind power capacity. The main changes of installed wind power capacity occurred in 2012, when $73 \mathrm{MW}$ of wind power were added. Later, the installed capacity increased slightly from 275 to $282 \mathrm{MW}$ in 2014. Although the RMSE and total installed power capacity increased from 2010 to 2012, relative wind power prediction errors decreased from 2010 to 2014 (Fig. 6). One of the main reasons for this

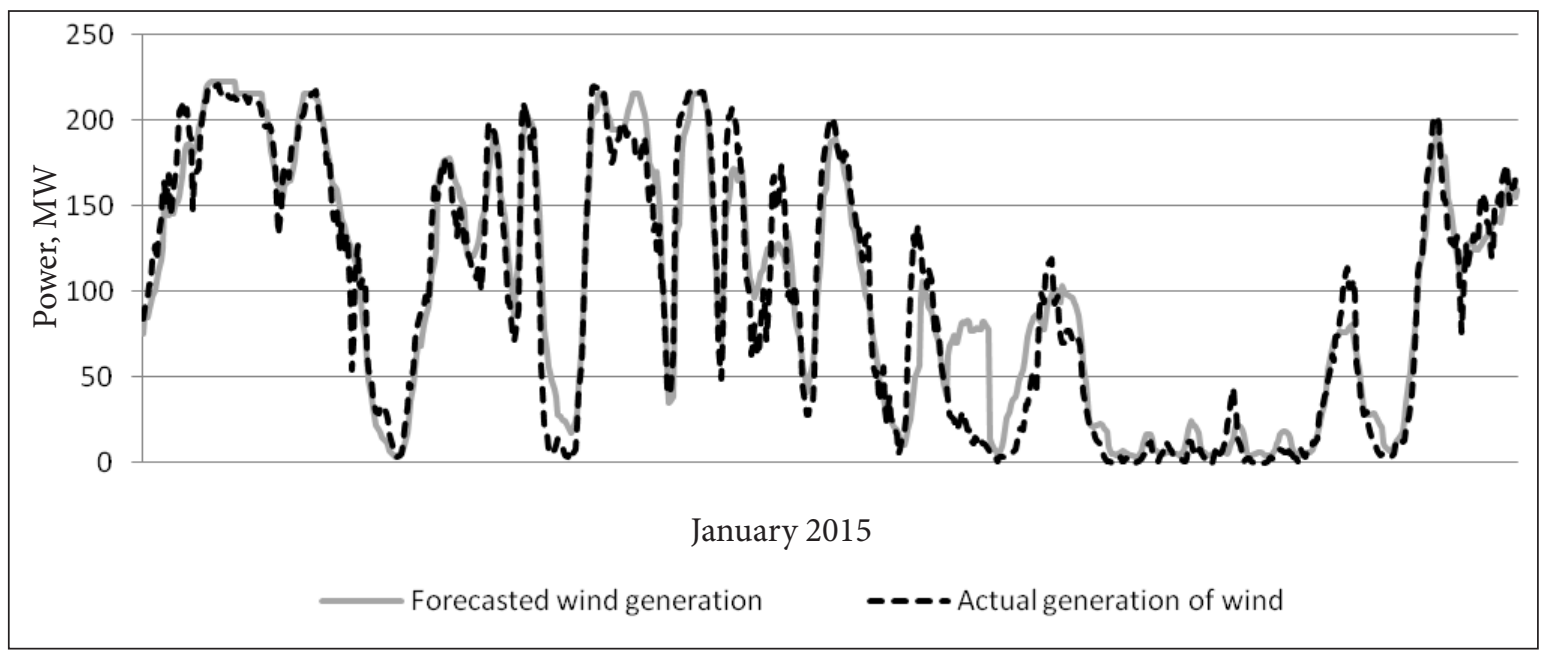

Fig. 4. Variation of Lithuanian wind farm power in January 2015

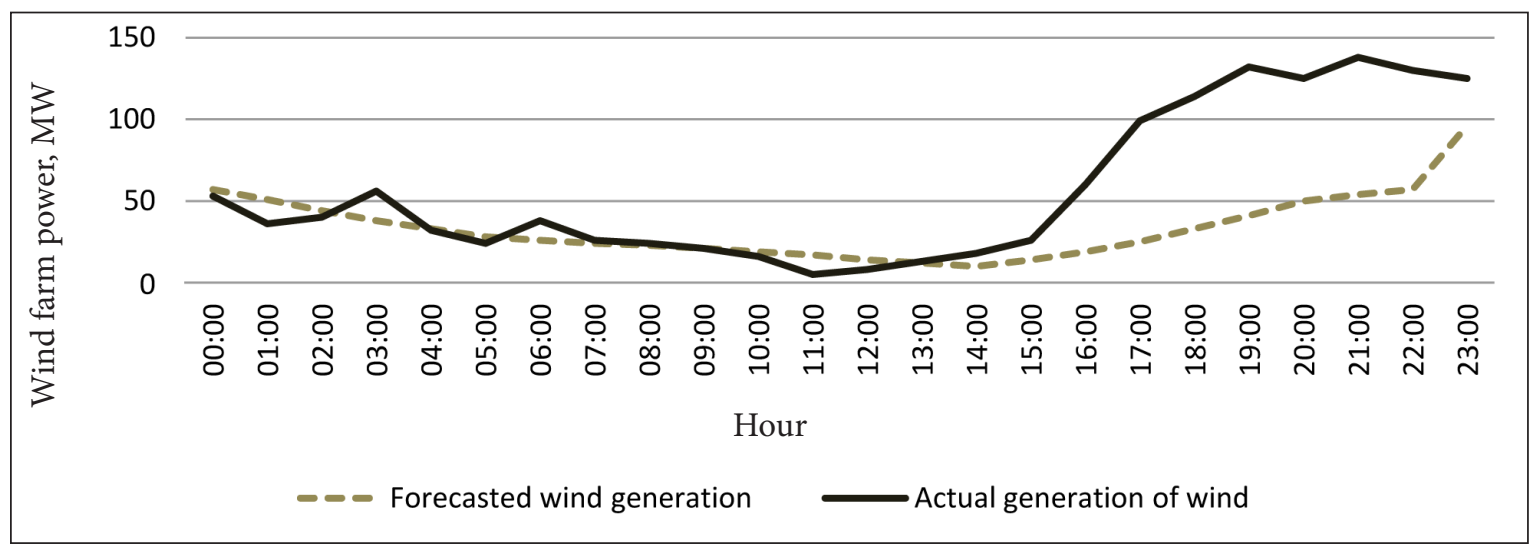

Fig. 5. Example of the diurnal variation of Lithuanian wind farm power 
could be the incorporation of historical wind power and wind speed data into the prediction model - last few years' wind power predictions were analysed, and data were adopted for the model.

An analysis of seasonal components provides detailed variation of wind power yield [16]. As it was mentioned before, wind power prediction was getting more accurate from 2010 to 2014 . To compare, there was a difference of 5 percentage points between summer (4.79\%) and winter (9.87\%) prediction errors in 2010 and only 1.33 percentage points between summer (4.72\%) and winter $(6.06 \%)$ in 2014 . It means that seasonal impact on prediction accuracy has gradual- ly decreased (Fig. 7). In 2010-2014, the largest prediction error values were found in winter $(9.87 \%)$ and the smallest in summer (4.72\%). This implies that the higher the wind speed, the lower the wind power prediction accuracy.

The main reason which could explain the difference in the seasonal errors is that in winter and autumn, when diurnal temperature changes gain significant values, they result in higher wind speed variations, and in summer, wind speeds are typically lower [22,23]. This confirms that higher wind speeds are associated with larger wind power prediction errors.

The diurnal wind power prediction error variation is presented in Fig. 8. The lowest error values

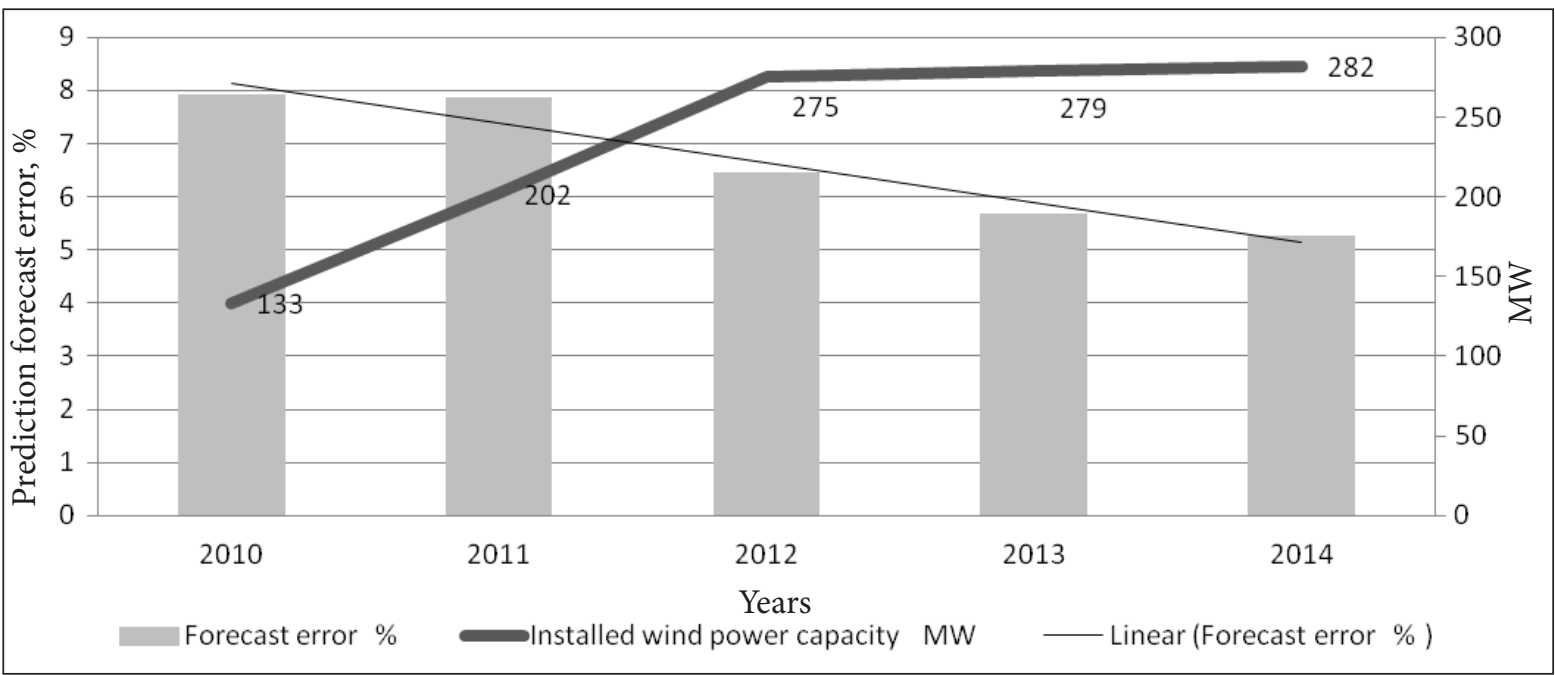

Fig. 6. Installed wind power capacity and power prediction errors in 2010-2014

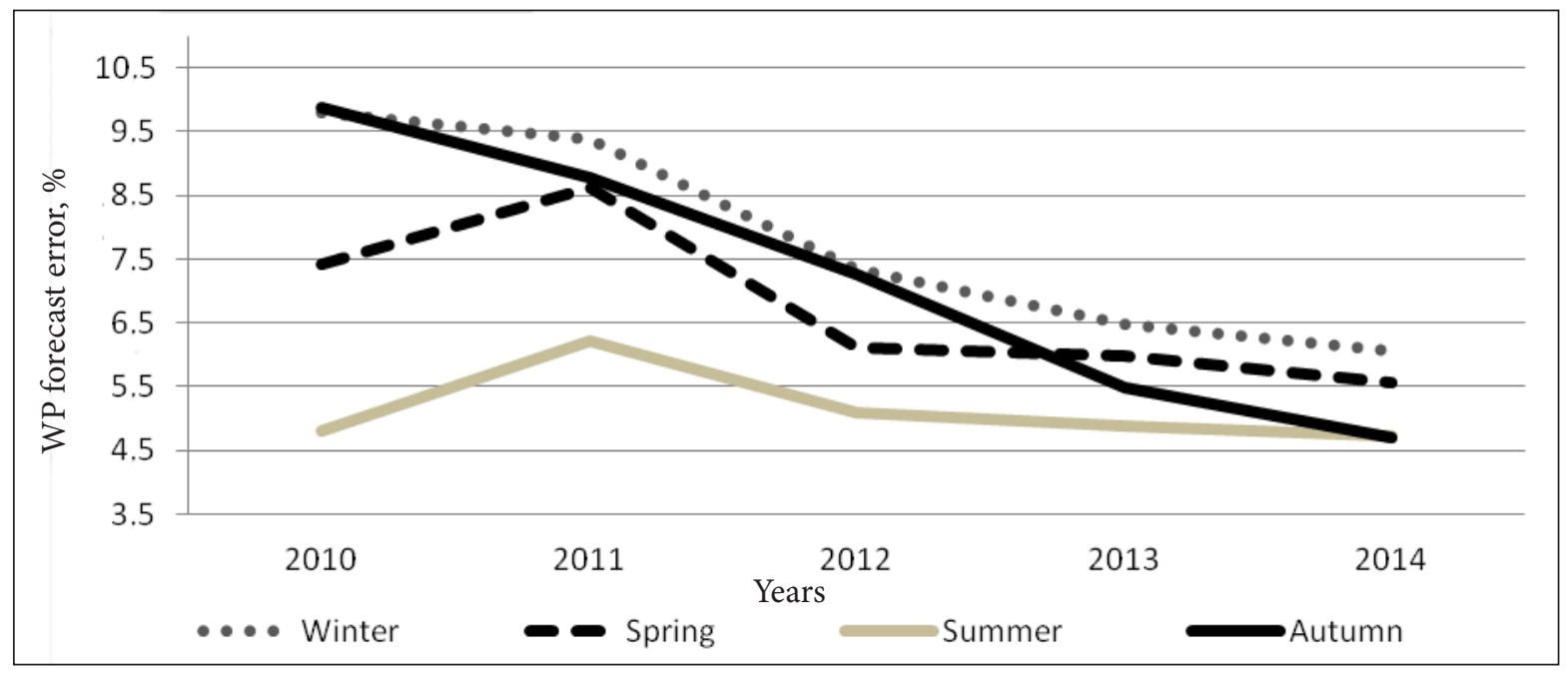

Fig. 7. Seasonal wind power prediction errors in 2010-2014 
were found at 3:00, 6:00 and 9:00 $(5.85,6.17$, and $6.27 \%$ on average, respectively) in the morning, and the biggest at 18:00 ( 8.55 and $9.12 \%$ on average).

An explanation of this is diurnal wind variation regarding temperature inversion. At night, wind flow turbulence intensity and thermal inversion values are weak. In the morning, when the sun is rising, turbulence increases between lower and higher layers. Later, wind speed increases in boundary layers and reaches maximum values at noon [22]. After sunset, due to decreased layer friction, minimum wind speed values are reached.

\section{DISCUSSION}

In this work, the main attention is given to the prospects of wind power development in Lithuania. The potential of separate geographical regions is analysed regarding the grid connection possibilities and wind energy estimations. Due to the improvement of wind power technologies (higher towers and larger rotors resulting in higher capacity factors), wind power projects may become profitable even in the regions which previously were considered non-perspective because of comparatively lower wind resources. Wind power integration in the eastern side of the country may bring new challenges for the grid stability, which may require more accurate wind power predictions. For this reason, a more detailed investigation of wind conditions and topographic characteristics as well as improvement of wind power prediction accuracy is needed.

In Lithuania, one prediction system is used for the prediction of the total wind farm power.
Currently, the mean wind power prediction error reaches $5.9 \%$, which is a rather good accuracy as the majority of wind farms are operating in one region, western part of the country. Introduction of new wind farms in other regions may negatively influence the average power prediction error due to shortage of historical wind power generation data.

The results of the analysis have revealed the influence of seasonal and diurnal wind speed variations on prediction accuracy; therefore, it is important to carry out the investigation of seasonal and diurnal errors taking into account the wind speed variation and local topographic conditions [24]. Such investigation would lead to identification of the reasons of prediction errors.

\section{CONCLUSIONS}

The investigation has shown that considering the possibilities of wind power connection to the national grid and distribution of wind energy potential, northern and middle regions have the best perspectives for further wind power development in Lithuania. Eastern and southern regions are characterized as having the lowest wind energy potential.

Analysis of total average wind power prediction errors shows increase in prediction accuracy during the period of 2010-2014. The difference between the annual seasonal prediction errors in summer and winter has decreased from 5 to 1.33 percentage points in 2010 and 2014, respectively. This indicates the significance of the amount of historical wind power generation data used for the statistical prediction model.

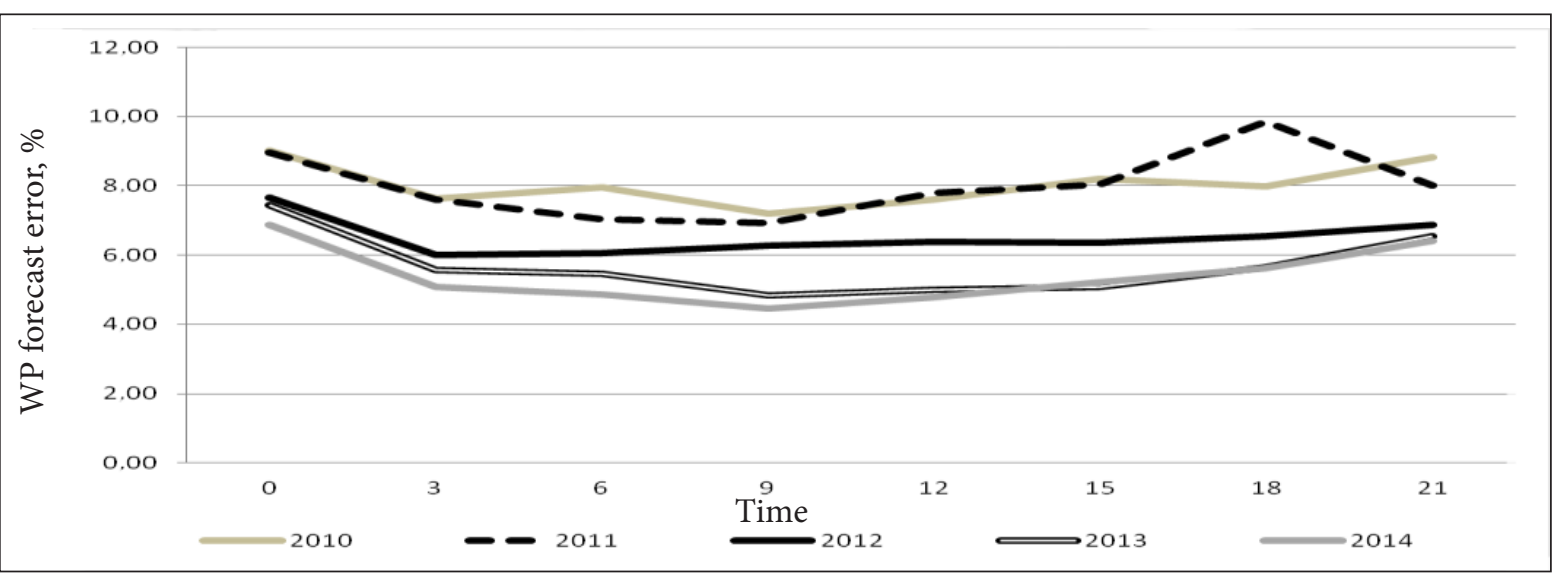

Fig. 8. Diurnal wind power prediction errors 
Analysis of seasonal and diurnal average wind power prediction errors revealed an inverse relation between the average wind speed values and wind power prediction accuracy. Higher average wind speeds lead to larger errors. Comparatively largest errors occur in the evening time (18:00), and the smallest at 3:00, 6:00 and 9:00. Considering the total five-year period, the largest estimated average wind power prediction errors occur in winter.

Received 17 March 2016 Accepted 15 May 2016

\section{References}

1. REN21. Renewables 2015 Global Status Report, Paris: REN21 Secretariat, 2015.

2. Statistics Lithuania. 2015. http://osp.stat.gov.lt/ statistiniu-rodikliu-analize id $=5821$ \&status $=\mathrm{A}$

3. Singh B., Singh S. N. Wind power interconnection into the power system: a review of grid code requirements. Electricity Journal. 2009. Vol. 22. P. 54-63.

4. Madariaga A., Martín J. L., Zamora I., Martínez De Alegría I., Ceballos S. Technological trends in electric topologies for offshore wind power plants. Renewable and Sustainable Energy Reviews. 2013. Vol. 24. P. 32-44.

5. Colak I., Sagiroglu S., Yesilbudak M. Data mining and wind power prediction: a literature review. Renewable Energy. 2012. Vol. 46. P. 241-247.

6. Meegahapola L., Perera S. Capability constraints to mitigate voltage fluctuations from DFIG wind farms when delivering ancillary services to the network. International Journal of Electrical Power \& Energy Systems. 2014. Vol. 62. P. 152-162.

7. Yan J., Lin H., Feng Y., Zhu Z. Q. Control of a grid-connected direct-drive wind energy conversion system. Renewable Energy. 2014. Vol. 66. P. 371-380.

8. Yu D., Liang J., Han X., Zhao J. Profiling the regional wind power fluctuation in China. Energy Policy. 2011. Vol. 39. No. 1. P. 299-306.

9. Focken U., Lange M., Waldl H. P. Previento - a wind power prediction system with an innovative upscaling algorithm. European Wind Energy Conference \& Exhibition, Copenhagen, 2003.
10. Hu J., Wang J., Zeng G. A hybrid forecasting approach applied to wind speed time series. Renewable Energy. 2013. Vol. 60. P. 185-194.

11. Albadi M. H., El-Saadany E. F. Overview of wind power intermittency impacts on power systems. Electric Power Systems Research. 2010. Vol. 80. No. 6. P. 627-632.

12. Lei M., Shiyan L., Chuanwen J., Hongling L., Yan Z. A review on the forecasting of wind speed and generated power. Renewable and Sustainable Energy Reviews. 2009. Vol. 13. P. 915920.

13. Stathopoulos C., Kaperoni A., Galanis G., Kallos G. Wind power prediction based on numerical and statistical models. Journal of Wind Engineering and Industrial Aerodynamics. 2013. Vol. 112. P. 25-38.

14. De Giorgi M. G., Ficarella A., Tarantino M. Error analysis of short term wind power prediction models. Applied Energy. 2011. Vol. 88. No. 4. P. 1298-1311.

15. Foley M., Leahy P. G., Marvuglia A., McKeogh E. J. Current methods and advances in forecasting of wind power generation. Renewable Energy. 2012. Vol. 37. No. 1. P. 1-8.

16. Zhang W., Wu J., Wang J., Zhao W., Shen L. Performance analysis of four modified approaches for wind speed forecasting. Applied Energy. 2012. Vol. 99. P. 324-333.

17. Roy S. Performance prediction of active pitchregulated wind turbine with short duration variations in source wind. Applied Energy. 2014. Vol. 114. P. 700-708.

18. Khosravi A., Nahavandi S. An optimized mean variance estimation method for uncertainty quantification of wind power forecasts. International Journal of Electrical Power \& Energy Systems. 2014. Vol. 61. P. 446-454.

19. Hameed Z., Ahn S. H., Cho Y. M. Practical aspects of a condition monitoring system for a wind turbine with emphasis on its design, system architecture, testing and installation. Renewable Energy. 2010. Vol. 35. No. 5. P. 879-894.

20. Ray M. L, Rogers L., McGowan J. G. Analysis of wind shear models and trends in different terrains. Proceedings of American Wind Energy Association Wind Power, June 2006, Pittsburgh, PA, USA. 
21. Horgan C. Using energy payback time to optimise onshore and offshore wind turbine foundations. Renewable Energy. 2013. Vol. 53. P. 287-298.

22. Burton T., Sharpe D., Jenkins N., Bossanyi E. Wind Energy Handbook. Chichester: John Wiley \& Sons, 2001.

23. Cheng M., Zhu Y. The state of the art of wind energy conversion systems and technologies: a review. Energy Conversion and Management. 2014. Vol. 88. P. 332-347.

24. Petersen E. L., Mortensen N. G., Landberg L., Højstrup J., Frank H. P. Wind power meteorology. Wind Energy. 1997. Vol. 1206. P. 2-22.
Giedrius Gecevičius, Mantas Marčiukaitis, Antanas Markevičius, Vladislovas Katinas

\section{VĖJO ENERGETINIŲ IŠTEKLIŲ IR TRUMPALAIKĖS ELEKTRINIŲ GALIOS PROGNOZĖS VERTINIMAS LIETUVOJE}

\section{Santrauka}

2015 m. Lietuvoje vejjo elektrinių instaliuotoji galia pasiekè $422 \mathrm{MW}$ ir tai yra viena iš labiausiai besiplečiančių atsinaujinančios energetikos sričių. Dèl šios priežasties svarbu įvertinti vejjo energetikos potencialą bei VE galios prognozès tikslumo tendencijas. Atlikta statistinè vejjo greičio ir krypties analizè, remiantis Veibulo skirstiniu bei vejų rože, identifikuoja vejo galios pasiskirstymo potencialą Lietuvoje. Išnagrinètos vèjo elektrinių galios prognozès paklaidos metinių, sezoninių ir valandinių periodų intervalais rodo paklaidų priklausomybę nuo sezoniškumo bei paros laiko. Analizè identifikuoja mažėjantị paklaidų skirtumą tarp sezonų ir išliekančias panašių verčių galios prognozavimo paklaidas dienos laikotarpiu (skirtingomis valandomis). Straipsnyje taip pat nagrinejjamos elektros energijos perdavimo tinklo galimybès prijungti vejo elektrinių parkus. Atliktas tyrimas rodo, kad tolimesnei vejjo energetikos plètrai, siekiant iki $840 \mathrm{MW}$ padidinti instaliuotąją VE galią iki 2030 m., tinkamiausi regionai yra Šiaurès ir vidurio Lietuva.

Raktažodžiai: vejjo energija, energetinis potencialas, galios prognozavimas 